Journal of Animal and Veterinary Advances 11 (12): 2116-2120, 2012

ISSN: $1680-5593$

(C) Medwell Journals, 2012

\title{
Ammonia Emissions from Dairy Cattle Barns in Summer Season
}

\author{
Ercan Simsek, Ilker Kilic, Erkan Yaslioglu and Ismet Arici \\ Department of Biosystems Engineering, Faculty of Agriculture, \\ Uludag University, 16059 Campus of Gorukle, Bursa, Turkey
}

\begin{abstract}
The objective of this study was to determine magnitude of ammonia emissions from dairy cattle freestall barns with natural ventilation. The measurements of ammonia concentration and indoor environmental conditions in barns were done throughout the 4 days in three dairy farms in summer season. The overall hourly average temperature and relative humidity for all barns were $26.5^{\circ} \mathrm{C}$ and $61 \%$, respectively. In monitored dairy cattle barns, ammonia concentrations were observed between 0.4 and $8.77 \mathrm{ppm}$. The overall hourly average ammonia emission was calculated as $56.1 \mathrm{~g} / \mathrm{h}$.barn. Ammonia concentrations increased with lower airflow rate while ammonia emissions increased with higher airflow rate. As a result of this study, there is no significant relationship observed between ammonia emission and indoor environmental conditions such as temperature and relative humidity.
\end{abstract}

Key words: Air pollutants, air quality, airflow rate, ammonia emissions, dairy cattle barns, indoor temperature

\section{INTRODUCTION}

Dairy cattle operations emit air pollutants such as Ammonia $\left(\mathrm{NH}_{3}\right)$, methane $\left(\mathrm{CH}_{4}\right)$, Hydrogen Sulfur $\left(\mathrm{H}_{2} \mathrm{~S}\right)$, Carbon Dioxide $\left(\mathrm{CO}_{2}\right)$, particulate matter and Volatile Organic Compounds (VOC). The gaseous pollutants are the products of the microbial decomposition of dairy cattle manures. The primary mechanism for releases of particulate matter is the entrainment of feeds, dry manure, soil and other material caused by movement of dairy cattle in both indoor and outdoor confinement. The magnitude of gaseous and particulate matter pollutants emission is closely related to floor layout, capacity of dairy barn and number of dairy cattle housed in unit floor area in barns. The air pollutant emissions increase with high density in barn. Therefore, intensive dairy cattle production techniques cause to emit high quantity of air pollutants.

Ammonia emissions from dairy cattle barns have some important impacts on environment surrounding barns. High concentrations of ammonia in atmosphere cause eutrophication and acidification in ecosystem. Thus play an important role in the decline of biodiversity and dying of forests (Amon et al., 2001). Since, ammonia is the primary basic gas in the atmosphere, it readily reacts with strongly acidic species in the atmosphere such as nitric and sulfuric acid to form ammonium salts also known as secondary particles, fine particulate matter or PM 2.5 (particles $<2.5 \mu$ in diameter) (Marcillac, 2007). Additionally, ammonia is an odorant and conditions conducive to the production of ammonia may result in the emission of other odorants (Redwine et al., 2002). Therefore, determination of ammonia emission rates is needed to reveal dairy cattle operation's impact on local and regional air quality. There are many studies on ammonia emissions from dairy cattle barns in literature. But in Turkey, studies related to ammonia emissions from dairy cattle barns are limited.

Ammonia emissions from dairy cattle barns have studied more than other gases, particulate matter and odors. Brose et al. (1998) reported that average ammonia emission from free-stall barn with slatted floor and natural ventilation was $12.4 \mathrm{~g}$ day $^{-1}$. Animal Unit (AU) in summer time. Arogo et al. (2003) indicated that ammonia emission factors ranged from $14.8-23.5 \mathrm{~kg}_{\text {year }}{ }^{-1}$. per dairy cattle. Schmidt et al. (2002) measured ammonia concentrations in a 550 cow free-stall barn with scraped alleys and found $240 \mathrm{ppb}$ in Winter season and $1140 \mathrm{ppb}$ in Summer season. Jungbluth et al. (2001) stated that ammonia emissions from dairy cattle building with slatted floor changed between 14-18 g/day.AU in June. Snell et al. (2003) determined ammonia and methane concentrations in four naturally ventilated dairy barns with an eave to ridge ventilation. They found that ammonia emissions varied from $113-322 \mathrm{~g} \mathrm{~h}^{-1}$.

The aim of this study was to quantify ammonia emissions from dairy cattle free-stall barns with natural ventilation. To assess variations in ammonia emissions, the measurements of ammonia concentration and indoor environmental conditions in three dairy cattle barns were carried out throughout the 4 days in summer season. All sectors of the dairy cattle barns were to be included in the measurements. The results of this study were compared with other studies under similar conditions in the literature.

Corresponding Author: Ilker Kilic, Department of Biosystems Engineering, Faculty of Agriculture, Uludag University, 16059 Campus of Gorukle, Bursa, Turkey 
Table 1: The dimensions of investigated dairy cattle barns

\begin{tabular}{|c|c|c|c|c|c|c|c|c|c|}
\hline \multirow[b]{2}{*}{ Barn } & \multirow[b]{2}{*}{ Barn width (m) } & \multirow[b]{2}{*}{ Barn length (m) } & \multirow[b]{2}{*}{ Wall height (m) } & \multirow[b]{2}{*}{ Ridge slope (m) } & \multirow[b]{2}{*}{ Roof slope (degree) } & \multicolumn{2}{|c|}{ Window dimensions } & \multicolumn{2}{|c|}{ Door dimensions } \\
\hline & & & & & & Length (m) & Width (m) & Length (m) & Width (m) \\
\hline Barn 1 & 21.3 & 41.6 & 4.5 & 6.3 & 23 & 4.1 & 0.70 & 3.0 & 4.9 \\
\hline Barn 2 & 12.5 & 21.3 & 4.0 & 6.0 & 18 & 3.0 & 1.50 & 2.8 & 2.8 \\
\hline Barn 3 & 14.8 & 47.7 & 3.0 & 6.5 & 25 & 4.7 & 0.75 & 2.7 & 7.0 \\
\hline
\end{tabular}

\section{MATERIALS AND METHODS}

In this study, measurements were carried out at three dairy cattle barns in Bursa in Northwest Turkey during summer seasons in 2010. The concentrations of $\mathrm{NH}_{3}$ and climatic data such as indoor temperature, relative humidity and air velocity in each dairy cattle barns were measured continuously $24 \mathrm{~h}$ for 4 days in summer season.

The capacity of investigated dairy cattle barns was changed 40-72 cows depending on time of year and calving. The dimensions of investigated dairy cattle barns were shown in Table 1. The dimensions of Barn I-III were $21.3 \times 41.6,7.1 \times 21.3$ and $14.8 \times 47.7 \mathrm{~m}$, respectively. All of dairy cattle barns had natural ventilation system. The dairy cattle were milked twice in a day between 07:0009:00 and 17:00-19:00. The manure management system for all barns was slurry manure system and manure was removed with a combination of hand and automatic scraper. The manure was scraped once a day in Barn I and II and a number of times in a day in Barn III. The dairy cattle number per unit floor area was ranged from $0.05-0.10 \mathrm{AU} \mathrm{m}^{-2}$.

The measurements of all variables were done 4 consecutive days in all barns for summer season under Bursa region conditions in Turkey. The horizontally and vertically center point of the barn was selected as measurement point for ammonia concentration and indoor environmental conditions such as temperature, relative humidity and air velocity. The concentration of ammonia was obtained from portable multiple gas detector (Ibrid MX6 Industrial Scientific, USA). Indoor environmental conditions were measured multi-function temperature and humidity meter with hot-wire probe (Model 350 XL-454, TestoAG, Germany).

For each barn, ventilation rate was calculated using air velocity and area of ventilation opening (Eq. 1).

Where:

$$
\mathrm{Q}=\mathrm{A} . \mathrm{V}
$$

$\mathrm{Q}=$ Ventilation rate $\left(\mathrm{m}^{3} / \mathrm{h} \cdot\right.$ barn $)$

$A=$ Area of ventilation opening $\left(\mathrm{m}^{2}\right)$

$\mathrm{V}=$ Air velocity $\left(\mathrm{m} \mathrm{sec}^{-1}\right)$

Ammonia emissions from the barns were determined according to Eq. 2, given by Hinz (1998).
Where:

$$
\mathrm{ER}=\mathrm{C} \cdot \mathrm{Q}
$$

$\mathrm{ER}=$ Emission Rate (g/h.barn)

$\mathrm{C}=$ Ammonia concentration (ppm)

$\mathrm{Q}=$ Ventilation rate $\left(\mathrm{m}^{3} / \mathrm{h} \cdot\right.$ barn $)$

The data obtained during whole study period were analyzed using Minitab 15. The regression analysis was done to reveal relationship between indoor environmental conditions and ammonia concentration and emission. Additionally, the significance of difference between day and night time ammonia emissions wasn't significant according to results of the variance analysis ( $\mathrm{p}>0.05)$.

\section{RESULTS AND DISCUSSION}

Indoor environmental conditions: The daily average indoor temperatures, Relative Humidity $(\mathrm{RH})$, air velocity and airflow rates are shown in Table 2. The indoor temperatures during study were ranged from $17.6-36.9^{\circ} \mathrm{C}$. The overall average temperature for all barns was calculated $26.5^{\circ} \mathrm{C}$. The minimum and maximum values of indoor temperature were obtained in Barn 3. The indoor relative humidity averaged $61 \%$ for all barns. The airflow rate during monitored period ranged from $0.22-23.57 \mathrm{~m}^{3} / \mathrm{min}$.AU. The overall average airflow rate was $5.7 \mathrm{~m}^{3} / \mathrm{min}$.AU during study. The minimum ventilation rates were obtained Barn 3 . This was probably due to the insufficient area of ventilation openings which were located along the side walls. Also, minimum ventilation rates in Barn 3 caused to appear maximum indoor temperature in the same barn.

Ammonia concentrations: The some statistical parameters of ammonia concentrations measured in barns are shown in Table 3. Summer ammonia concentrations were observed between 0.4 and $8.77 \mathrm{ppm}$ in monitored barns. The overall average ammonia concentrations were $1.53 \mathrm{ppm}$ for Barn 1, $1.72 \mathrm{ppm}$ for Barn 2 and $3.74 \mathrm{ppm}$ for Barn 3. The maximum concentrations of ammonia were observed in Barn 3 because of lower ventilation rates.

The ammonia concentrations obtained in this study for dairy cattle barns are compatible with the literature. Brose et al. (1998) reported mean ammonia concentration from a dairy barns with natural ventilation as $4 \mathrm{ppm}$. The average ammonia concentration in dairy barns has been 


\section{J. Anim. Vet. Adv., 11 (12):2116-2120, 2012}

Table 2: Indoor temperature, relative humidity and airflow rate in dairy cattle barns ( $\mathrm{n}=570)$

\begin{tabular}{|c|c|c|c|c|c|}
\hline Barn & Parameter & $\begin{array}{c}\text { Temperature } \\
\left(\begin{array}{l}\left.{ }^{\circ} \mathrm{C}\right) \\
\mathrm{r}\end{array}\right.\end{array}$ & $\begin{array}{c}\mathrm{R} . \\
\text { humidity }(\%)\end{array}$ & $\begin{array}{l}\text { Air velocity } \\
\left.(\mathrm{m} \mathrm{sec})^{-1}\right)\end{array}$ & $\begin{array}{l}\text { Airflow rate } \\
\left(\mathrm{m}^{3} / \mathrm{min} . \mathrm{AU}\right)\end{array}$ \\
\hline \multirow[t]{4}{*}{ Barn 1} & Avg & 26.85 & 62.51 & 0.18 & 8.52 \\
\hline & Max & 33.10 & 82.80 & 0.50 & 23.57 \\
\hline & Min & 21.19 & 40.82 & 0.04 & 1.76 \\
\hline & SD & 3.39 & 9.97 & 0.11 & 5.20 \\
\hline \multirow[t]{4}{*}{ Barn 2} & Avg & 27.63 & 55.53 & 0.19 & 3.54 \\
\hline & Max & 36.93 & 75.37 & 0.85 & 15.56 \\
\hline & Min & 20.27 & 31.07 & 0.01 & 0.24 \\
\hline & SD & 3.97 & 10.16 & 0.17 & 3.03 \\
\hline \multirow[t]{4}{*}{ Barn 3} & Avg & 24.93 & 65.72 & 0.73 & 0.98 \\
\hline & $\operatorname{Max}$ & 30.56 & 84.64 & 4.34 & 5.73 \\
\hline & Min & 17.60 & 43.46 & 0.16 & 0.22 \\
\hline & SD & 3.53 & 11.63 & 0.48 & 0.64 \\
\hline
\end{tabular}

Table 3: Some parameters of ammonia concentrations in dairy cattle barns

\begin{tabular}{lccccc}
\hline & & \multicolumn{3}{c}{$\mathrm{NH}_{3}$ concentrations (ppm) } & \\
Dairy cattle bams & $\begin{array}{c}\text { Measurement } \\
\text { days }\end{array}$ & Avg. & Max. & Min. & SD \\
\hline Barn 1 & 1 & 0.910 & 1.060 & 0.760 & 0.120 \\
& 2 & 0.820 & 1.650 & 0.550 & 0.290 \\
& 3 & 1.380 & 2.310 & 0.800 & 0.460 \\
Barn 2 & 4 & 2.220 & 4.440 & 0.830 & 1.260 \\
& 1 & 0.900 & 1.500 & 0.650 & 0.270 \\
& 2 & 0.790 & 1.550 & 0.390 & 0.310 \\
Barn 3 & 3 & 0.770 & 1.240 & 0.480 & 0.240 \\
& 4 & 0.740 & 0.990 & 0.520 & 0.160 \\
& 1 & 1.140 & 1.440 & 0.850 & 0.200 \\
& 2 & 1.440 & 2.280 & 0.790 & 0.510 \\
& 3 & 1.640 & 3.530 & 0.500 & 1.090 \\
& 4 & 3.630 & 8.770 & 0.670 & 2.810 \\
& & & & &
\end{tabular}

reported as $5.3 \mathrm{ppm}$ (Jungbluth et al. 2001) and $8.2 \mathrm{ppm}$ (Snell et al., 2003). Zhang et al. (2005) indicated that ammonia concentrations in dairy cattle barns were changed from 2.1-20 ppm. The range of ammonia concentrations was given between 0.8 and $5.6 \mathrm{ppm}$ in Zhao et al. (2007).

Ammonia emissions: The average ammonia emissions from monitored dairy cattle barns were shown in Table 4. Ammonia emission varied from $0.62-2517.9 \mathrm{~g} / \mathrm{h}$.barn. During study, the average ammonia emission was calculated as $19.3 \mathrm{~g} / \mathrm{h}$.barn for Barn 1, $8.1 \mathrm{~g} / \mathrm{h}$.barn for Barn 2 and $115 \mathrm{~g} / \mathrm{h}$. barn for Barn 3 . The minimum ammonia emission was occurred in Barn 2 while maximum ammonia emission was observed in Barn 3. Because concentration of ammonia in Barn 3 was approximately two times higher than in Barn 2. Moreover, overall ammonia emission rates per dairy cattle were found $17.7 \mathrm{~g} /$ day.AU for whole study period.

The ammonia emissions obtained in this study were higher than ammonia emissions reported in the literature. This was probably due to differences in building design, outdoor environmental conditions and ventilation systems. Also, dairy cattle producer in Europe and USA must decrease the amount of nitrogen in feed rations due to legal regulations to limit ammonia emissions from their
Table 4: The some parameters of ammonia emissions from dairy cattle barns

\begin{tabular}{|c|c|c|c|c|c|}
\hline \multirow[b]{2}{*}{ Dairy cattle bams } & \multirow{2}{*}{$\begin{array}{c}\text { Measurement } \\
\text { days }\end{array}$} & \multicolumn{4}{|c|}{$\mathrm{NH}_{3}$ emissions (g/h.barn) } \\
\hline & & Avg. & Max. & Min. & $\mathrm{SD}$ \\
\hline \multirow[t]{4}{*}{ Barn 1} & 1 & 11.39 & 24.61 & 4.45 & 7.63 \\
\hline & 2 & 12.91 & 36.11 & 2.79 & 10.45 \\
\hline & 3 & 22.86 & 47.43 & 4.99 & 12.84 \\
\hline & 4 & 30.15 & 81.34 & 7.84 & 17.48 \\
\hline \multirow[t]{4}{*}{ Barn 2} & 1 & 13.97 & 35.89 & 0.87 & 9.11 \\
\hline & 2 & 9.89 & 28.41 & 0.67 & 9.42 \\
\hline & 3 & 7.31 & 26.32 & 0.66 & 7.67 \\
\hline & 4 & 0.86 & 1.26 & 0.62 & 0.25 \\
\hline \multirow[t]{4}{*}{ Barn 3} & 1 & 67.26 & 495.36 & 11.22 & 7.68 \\
\hline & 2 & 84.96 & 784.32 & 10.43 & 19.58 \\
\hline & 3 & 96.76 & 1214.32 & 6.60 & 41.86 \\
\hline & 4 & 214.17 & 2517.88 & 8.84 & 107.90 \\
\hline
\end{tabular}

Table 5: The variations of $\mathrm{NH}_{3}$ concentration and emission among dairy cattle barns

\begin{tabular}{lcc}
\hline Barn & $\mathrm{NH}_{3}$ concentrations $(\mathrm{ppm})$ & $\mathrm{NH}_{3}$ emissions $\left(\mathrm{g} \mathrm{h}^{-1}\right)$ \\
\hline B1 & $1.33^{\mathrm{ab}}$ & $19.33^{\mathrm{b}}$ \\
B2 & $0.80^{\mathrm{b}}$ & $8.01^{\mathrm{c}}$ \\
B3 & $1.96^{\mathrm{a}}$ & $115.80^{\mathrm{a}}$ \\
Dairy cattle bam & - & - \\
\hline
\end{tabular}

${ }^{\mathrm{a}-\mathrm{c}}$ Means in a column with different superscripts signific antly differ

barns. This application causes less ammonia emissions from animal feeding operations. Therefore, the ammonia emissions reported in literature are smaller than ammonia emissions calculated in this study. Brose et al. (1998) reported mean ammonia emission rate as $12.4 \mathrm{~g} /$ day.AU. Amon et al. (2001) presented that ammonia emissions per dairy cattle were changed from 3.9-7.4 g/day.AU. Mutlu et al. (2004) indicated that ammonia emissions rate was $2.6 \mathrm{~g}$ /day.AU for dairy cattle in summer season.

The variation in ammonia concentration and emission: Table 5 shows variation in ammonia concentrations and emissions among monitored dairy cattle barns. In this study, the differences in ammonia concentrations and emissions were found to be significant among dairy cattle barns $(p<0.05$ and $p<0.01)$. This variation among barns was probably due to differences in building design, management strategies, manure management systems and ventilation system design.

The diurnal variation of ammonia concentration and emissions were shown in Fig. 1. The ammonia concentrations in night time were higher than that in day time due to lower airflow rates and animal activity. It assumed that airflow rate and animal activity have effects on minimum and maximum values of ammonia concentrations in dairy cattle barns. The maximum values of ammonia emission were observed in noon hours (12:00-14:00) while lowest ammonia emissions observed in night time between 00:00 and 02:00. The trend of hourly ammonia emission rates followed airflow rates during study. Therefore, it can be said that airflow rate and 

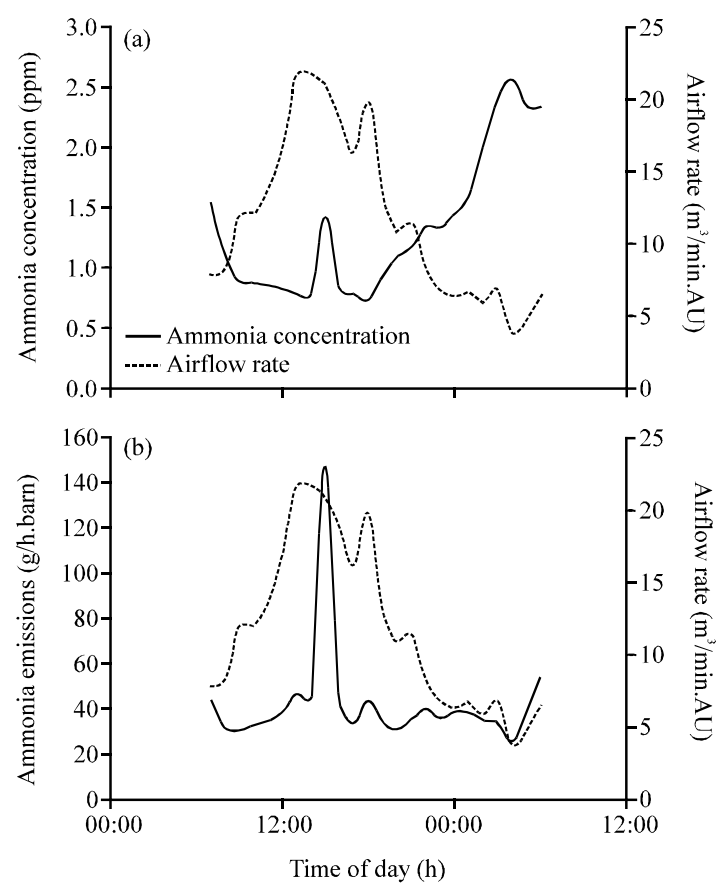

Fig. 1: The diurnal variation of a) ammonia concentration and b) emissions
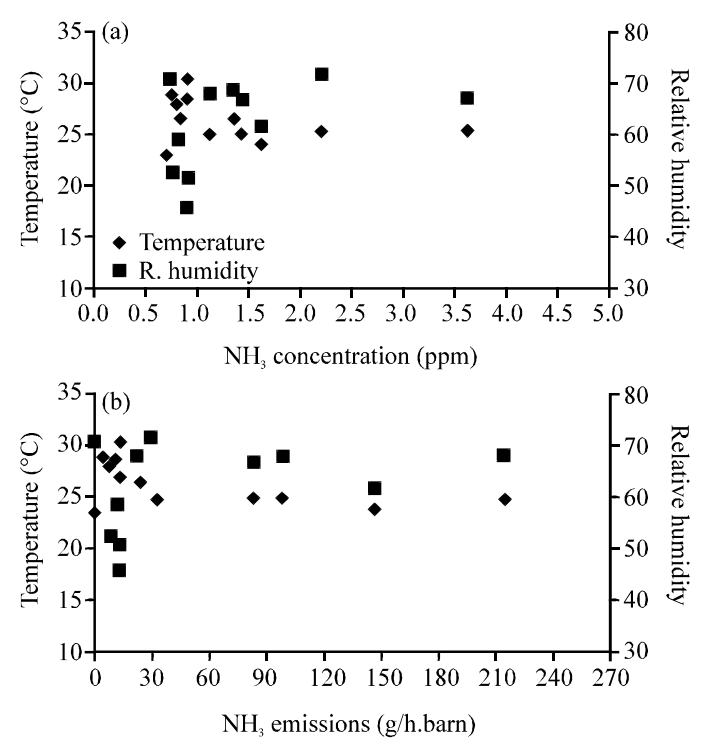

Fig. 2: The relationship between indoor temperature and relative humidity and a) ammonia concentration and b) emissions

concentration affected magnitude of ammonia emission from barns. The result of regression analysis exhibited no significant relationship between ammonia emissions and airflow rate. Also, the differences between day time and night time values of ammonia concentrations and emission rates were not statistically significant in this study according to the results of variance analysis $(p>0.05)$. The one of this study's goals was to determine relationship between indoor environmental conditions and ammonia concentration and emission under Bursa conditions. Figure 2 shows indoor temperature and relative humidity versus ammonia concentrations and emission from dairy cattle barns. As a result of regression analysis, it wasn't obtained any significant relationship between indoor temperature and ammonia concentration and emission because magnitudes of $\mathrm{R}^{2}$ were too small. The same results were attained for relative humidity in regression analysis.

\section{CONCLUSION}

In this study, data were collected from three dairy cattle barns in Bursa in Northwest Turkey during summer season. The $\mathrm{NH}_{3}$ concentration indoor temperature, relative humidity and air velocity were measured continuously $24 \mathrm{~h}$ for 4 days each dairy cattle barns.

In monitored barns, ammonia concentrations were measured between 0.39 and $8.77 \mathrm{ppm}$. These values are compatible with concentrations reported in literature for dairy cattle barns. Ammonia emissions from dairy cattle barns ranged from $0.62-2518 \mathrm{~g} / \mathrm{h}$.barn. The airflow rate affected ammonia concentrations and emissions pattern during the study. Ammonia concentrations increased with lower airflow rate while ammonia emissions increased with higher airflow rate. As a result of this study, it was not found any relationship between ammonia emission and indoor environmental conditions such as temperature and relative humidity. For further study, animal activity measurement should be included to determine accurate ammonia emissions from dairy cattle barns.

\section{ACKNOWLEDGEMENT}

This study was funded by Scientific Research Project Unit of Uludag University as Project No.: Z-2008/69. The researchers would like to express appreciation for the cooperation of Dairy Cattle Producer in collecting this data.

\section{REFERENCES}

Amon, B., T.H. Amon, J. Boxberger and C.H. Alt, 2001. Emissions of $\mathrm{NH}_{3}, \mathrm{~N}_{2} \mathrm{O}$ and $\mathrm{CH}_{4}$ from dairy cows housed in a farmyard manure tying stall (housing, manure storage, manure spreading). Nut. Cycling Agroecosyst., 60: 103-113.

Arogo, J., P.W. Westerman and A.J. Heber, 2003. A review of ammonia emissions from confined swine feding operations. Trans. ASAE, 46: 805-817. 
Brose, G., E. Hartung and T. Jungbluth, 1998. Influences on and measurement of ammonia and greenhouse gas emissions from dairy houses. Proccedings of the International Conference on Agricultural Engineering, Oslo (Norway), August 24-27, 1998, Norges Landbrukshoegskole, NLH, Aas (Norway), pp: $279-280$.

Hinz, T.S., 1998. A comprehensive experimental study of aerial pollutants in and emissions from livestock buildings Part 2: Methods. J. Agric. Eng. Res., 70: 111-118.

Jungbluth, T., E. Hartung and G. Brose, 2001. Greenhouse gas emissions from animal houses and manure stores. Nut. Cycling Agroecosyst., 60: 133-145.

Marcillac, N.M., 2007. Characterization and quantification of air emissions from dairies. Ph.D. Thesis, Department of AnimalScience, Colorado State University, USA.

Mutlu, A., S. Mukhtar, S.C. Capareda, C.N. Boriack, R.E. Lacey, B.W. Shaw and C.B. Parnell, 2004. A process-based approach for ammonia emission measurement at a free-stall dairy. Proceedings of the ASAE/CSAE Annual International Meeting, August 1-4, 2004, ASAE/CSAE, Ottawa, Ontario, Canada, pp: $1-11$.
Redwine, J.S., R.E. Lacey, S. Mukhtar and J.B. Carey, 2002. Concentration and emissions of ammonia and particulate matter in tunnel ventilated broiler houses under summer conditions in Texas. Trans. ASAE, 45: 1101-1109.

Schmidt, D.R., L.D. Jacobson and K.A. Janni, 2002. Continuous Monitoring of Ammonia hydrogen Sulfide and Dust Emissions from Swine, Dairy and Poultry Barns. American Society of Agricultural and Biological Engineers, Illinois, USA.

Snell, H.G.J., F. Seipelt and H.F.A. Van Den Weghe, 2003. Ventilation rates and gaseous emissions from naturally ventilated dairy houses. Biosyst. Eng., 86: 67-73.

Zhang, G., J.S. Strom, B. Li, H.B. Rom, S. Morsing, P., Dahl and C. Wang, 2005. Emission of ammonia and other contaminant gases from naturally ventilated dairy cattle buildings. Biosyst. Eng., 92: 355-364.

Zhao, L.Y., M.F. Brugger, R.B. Manuzan, G. Arnold and E. Imerman, 2007. Variations in airquality of new Ohio dairy facilities with natural ventilation systems. Appl. Eng. Agric., 23: 339-346. 